\title{
Assessment of Sediment Load of Langtang River in Rasuwa District, Nepal
}

\author{
Aastha Chhetri, Rijan B. Kayastha, Ahuti Shrestha \\ Himalayan Cryosphere, Climate and Disaster Research Center, Department of Environmental Science and \\ Engineering, Kathmandu University, Dhulikhel, Nepal \\ Email: aastha_c@hotmail.com
}

Received 25 November 2015; accepted 22 January 2016; published 25 January 2016

Copyright (C) 2016 by authors and Scientific Research Publishing Inc.

This work is licensed under the Creative Commons Attribution International License (CC BY). http://creativecommons.org/licenses/by/4.0/

c) (i) Open Access

\section{Abstract}

This paper assesses the sediment load of the glacier fed Langtang River, Nepal from April 2014 to March 2015. Water samples were collected from the centre of the river with a frequency of two samples per each sampling day using the Depth Integration Technique (DIT) on daily basis in the monsoon season, weekly in the pre- and post-monsoon seasons and bi-monthly in the winter season. Suspended sediment concentration (SSC) is calculated from the water samples using filtration followed by oven-drying, and a rating curve is used to calculate daily discharge of the Langtang River. The annual sediment yield is $109,276.75$ tons and $37.69,11.52$ and 5.54 tons of sediment is transported per day in the pre-monsoon, post-monsoon and winter seasons, respectively. There is a very high value of 872.86 tons per day in the monsoon season, which contributes the highest sediment load among all of the seasons comprising $83 \%$ of the total sediment transport. Diurnal cycle of sediment discharge is clearly seen with higher sediment discharge during the evening than the morning and reaching maximum values of $41.1 \mathrm{~kg} \cdot \mathrm{s}^{-1}$ and $61.5 \mathrm{~kg} \cdot \mathrm{s}^{-1}$, respectively. A clock-wise hysteresis loop has been obtained for discharge and sediment discharge where sediment flux is higher in the early monsoon than in the late monsoon for a corresponding discharge.

\section{Keywords}

Sediment Load, SSC, Discharge, Depth Integration Technique, Langtang River

\section{Introduction}

Soil transport and deposition within river basins are the main natural processes that affect the geomorphology of river channels. The collision of the Indian and Eurasian plates created the highly elevated Himalayan Mountains with unstable geologic formations and large debris-covered glaciers that supply an immense amount of sediment 
to the river systems, thereby enhancing the depositional process [1]. Increased runoff during the summer monsoon transfers sediments into the streams and causes floods [2]. In the high mountain regions, glaciers scour the mountain slopes and increase the rate of erosion and transport of rocks and boulders to the lower valleys [3]. Meltwater generated from glacierized basins thus carries a significant amount of suspended sediment resulting in higher sediment yields [4] which also depends on the amount of water draining through the glacier [5]. A number of studies have demonstrated that specific sediment yield may increase downstream, due to remobilization of sediments pushed by the active glaciers [6]. In addition to that, capacity of rivers to transport suspended sediment is proportional to discharge and influenced by hydrologic properties of the drainage basin.

A sufficient amount of sediment is required to sustain ecosystems, including the flora and fauna that people depend on, but excessive amounts of sediment can place stress on a variety of species and habitats, and degrade water quality and aquatic-ecosystem health since contaminants and nutrients preferentially adsorb to fine sediments [7]. Glaciers in the Himalaya are retreating at high rates in recent decades [8], exposing the underlying soil and rocks and forming many unstable lakes. Rapid melting of glaciers is changing freshwater resources and their channeling along with the volume of water these channels carry. The impact of climate change is also visible by the thawing of permafrost, which enhances the potential for rockfalls and landslides in steep mountain terrain [9]. The main cause of erosion in the Himalayan region is its young, fragile geology and steep catchments [10], along with intense rainfall during the monsoon season. Himalayan rivers draining the tectonically active belts show very high sediment yields [11]. Runoff and sediment load changes are affected by climate change and human activities in an integrated way. Other than natural processes, activities like road construction, mining, over-grazing, deforestation and cultivation on steep slopes have accelerated erosion rates and ultimately increased sediment concentrations in the Himalayas [12]. The sediment loads of Himalayan rivers are amongst the highest in the world, resulting in problems such as the siltation of reservoirs, blockage of river channels, water pollution and degradation of aquatic environments [13]. Insight into these effects can not only improve the knowledge of river processes, but also promote more effective land and water management [14].

Studies of Himalayan glaciers show that about 70 percent of the sediment load emerging from a glacier at its terminus goes into temporary storage in the alpine watershed and subsequently is removed in periods of high discharge during the monsoonal months [11]. Studies of diurnal variations also suggest that suspended sediment corresponds to water discharge [15]. Natural disasters on the other hand are very frequent in the Nepalese Himalaya, which creates a tremendous volume of sediment load [16] and is influenced by the extreme relief and high monsoon rainfall. This becomes a big challenge for operation and maintenance of hydropower facilities which in Nepal are mostly located on rivers that are fed by runoff [17]. In the Langtang River catchment glaciers are retreating steadily with an estimation of 32\% reduction in glacier area by 2035, which will cause further exposure of rocks and soil and thus increase the amount of sediment runoff [18]. Sediment load is the most straight-forward way to estimate erosion [19]. Only a few studies have been done in this sector in our country, yet it is very important before the initiation of water-related projects, specifically hydro-power generation. Therefore, this study aims to provide knowledge on the amount of sediment that is being transported from the Himalayan region on a seasonal as well as diurnal basis. This may help to predict and prevent natural calamities and its major contribution is towards predicting feasibility for constructing hydropower plants downstream because snow and glacier melt runoff during melt season is of vital importance for hydroelectric power generation.

\section{Study Area}

The Langtang River catchment is situated approximately $60 \mathrm{~km}$ North of Kathmandu in the Langtang Valley of Rasuwa district, central Nepal (Figure 1). It is the headwater area of the Trisuli River in the Narayani River system. It covers a total area of $353.59 \mathrm{~km}^{2}$ with elevation ranging from $3652 \mathrm{~m}$ a.s.l. to $7215 \mathrm{~m}$ a.s.l. [20]. The glaciers of this catchment cover an area of $137.5 \mathrm{~km}^{2}$ while the remaining area of $216.1 \mathrm{~km}^{2}$ is covered by rock and vegetation. There is a gradual increase in the air temperature during the pre monsoon season from March to mid-June. The monsoon season, from mid-June to the end of the September, is dominated by positive air temperatures and more than $80 \%$ of annual precipitation falls during this season.

Only few studies have been done in this sector in the study area, which is actually very important before the initiation of water-related projects specially hydro-power plant. Therefore, this study aims to provide information about sediment yield and sediment discharge rate in Langtang River on a seasonal as well as diurnal basis. 


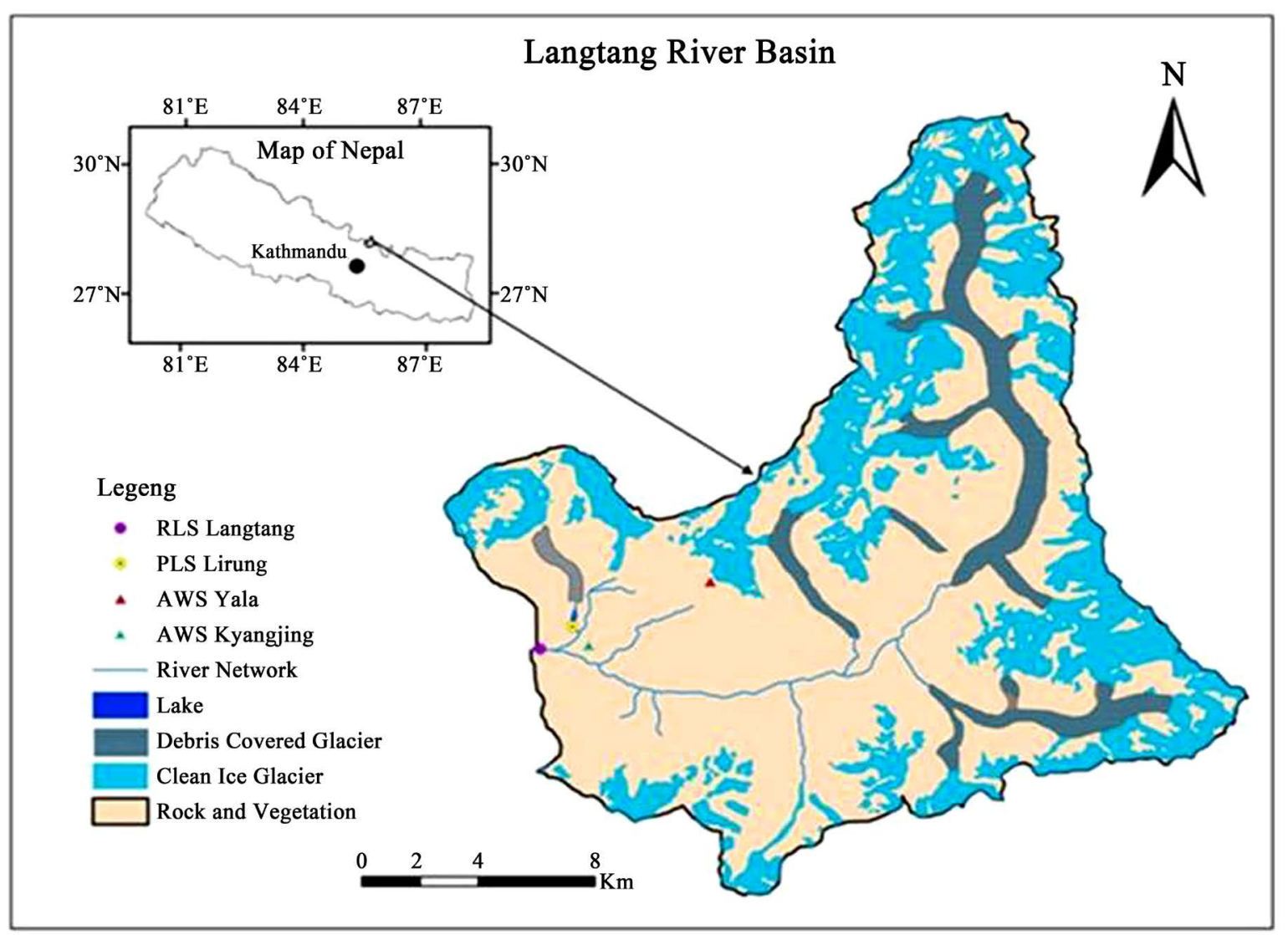

Figure 1. Map of Nepal showing Langtang catchment area [20].

\section{Materials and Methods}

\subsection{Sample Collection}

Suspended sediment is calculated for a year from April 2014 to March 2015 in this research from the water samples of Langtang River catchment. Pre monsoon includes months of March, April and May, monsoon includes June to September, Post monsoon includes October and November and the rest falls under winter season. Samples for pre-monsoon and post-monsoon season were collected on weekly basis that accounts to a total number of 24 and 16 samples respectively while for monsoon season 174 samples were collected on daily basis. And for winter season samples were collected once in two weeks which accounted to a total number of 18 samples. Stage height for discharge calculation was also collected on the same time period and frequency. Daily samples for Monsoon season is very important since high amount of precipitation occur at that time enhancing sediment transport while for pre monsoon only weekly sample is representative enough. The frequency of collection is however twice a day in the morning at $8 \mathrm{AM}$ and in the evening at $4 \mathrm{PM}$ for each sampling date to study the diurnal variation in sediment content.

\subsection{Sampling Technique}

The depth integration technique (DIT) was used for collecting water samples. For DIT the sampling bottle was submerged into the river and brought back to the surface at a constant rate [21] and the collected water sample is assumed to represent water at all river depths. Sample collection and filtration was done in the field as shown in Figure 2.

\subsection{Sampling Procedure}

First the sampling bottles were rinsed three times with river water before sampling. The collected samples were 


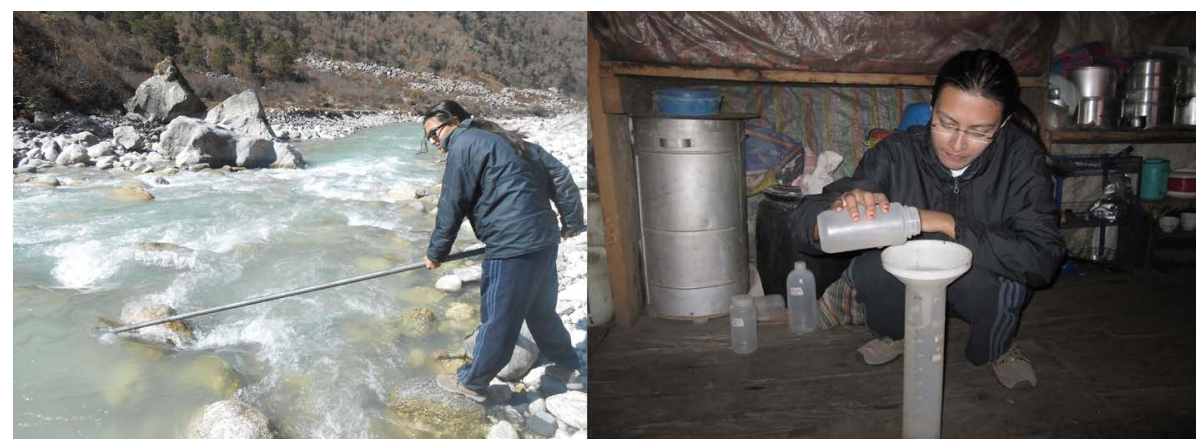

Figure 2. Sample collection and filtration done in the field.

then labeled with specifications like date, gauge height and time of sample collection. The collected sample was then filtered with filter-paper $(11 \mu \mathrm{m})$ and filters were stored in air-tight zip-lock bags preventing pollution and sediment loss. These zip-locked bags were later transported to Kathmandu University from the field for laboratory work. During the laboratory analysis the filtered papers with residue were first heated in a hot-air oven initially set at $103^{\circ} \mathrm{C}-105^{\circ} \mathrm{C}$ for an hour. Then the papers were allowed to cool in desiccator for about 15 minutes to stabilize temperature which were later weighed in a pre-calibrated weighing balance.

\subsection{Calculation}

The following equations were applied for sediment load (discharge) and discharge calculations after laboratory analysis.

$$
\text { Sediment Load }=\text { SSC } \times \text { Q }
$$

where SSC: Suspended Sediment Concentration $\left(\mathrm{mg} \cdot \mathrm{L}^{-1}\right)$; Q: discharge derived from the rating curve $\left(\mathrm{m}^{3} \cdot \mathrm{s}^{-1}\right)$

$$
\operatorname{SSC}=\frac{[(\mathrm{A}-\mathrm{B}) \times 1000]}{\mathrm{C}}
$$

where A: weight of filter paper + residue in mg; B: weight of filter paper in mg; C: water sample filtered in ml

$$
\mathrm{Q}=12.707 \times(\mathrm{G}-0.70905)^{0.6797}
$$

where G: gauge height in $\mathrm{m}$.

Sediment load is calculated using Equation (1) [21]. SSC is calculated with the help of Equation (2) [22] after laboratory analysis of the filter papers was complete. Discharge is calculated by using the rating curve (Equation (3)) obtained from discharges measured using area-velocity method at different occasions from 29 May 2008 to 19 June 2014 [23].

\subsection{Statistical Analysis}

Regression analysis and Kruskall Wallis $\mathrm{H}$ test is applied to test significance of seasonal and diurnal variation of sediment load of the Langtang Valley. The statistical software SPSS 15.0 and Microsoft Excel is used for this analysis. Since the data were not normally distributed, Kruskall Wallis $\mathrm{H}$ test was used to find the statistical significant among the seasons, while Regression analysis was used for finding the relation among sediment concentration, sediment load and discharge. R-squared value is computed during regression analysis which is a statistical measure to understand how close the data are to the fitted regression line which is also known as the coefficient of determination

\section{Results and Discussion}

The annual sediment yeild in Lantang River, Nepal was 109,276.75 tons in 2014-2015. The highest suspended sediment discharge of 872.86 tons day $^{-1}$ was found during the monsoon season. Volumes are relatively low in the pre-monsoon, post-monsoon and winter: $37.69,11.52$ and 5.54 tons $\cdot$ day $^{-1}$, respectively. This indicates that 
the maximum amount of sediment is transported during the monsoon season, accounting for $83 \%$ of the annual sediment transport. Thus suspended sediment discharge is following the pattern of discharge in different seasons, where maximums occur in the monsoon season and minimums occur in other seasons, as shown in Figure 3.

Sediment discharge reached a maximum morning value of $41.1 \mathrm{~kg} \cdot \mathrm{s}^{-1}$ and an evening maximum of 61.5 $\mathrm{kg} \cdot \mathrm{s}^{-1}$ (Figure 4). This clearly indicates the effect of high temperature and radiation during the daytime, which melts both clean and debris-covered glacier ice. Melt water from debris-covered glacier ice contributes to increasing the sediment content of the Langtang River and has a stronger influence in this systems than the dilution effect of melt water from clean ice glaciers [24]. The high sediment concentrations during the high flow (monsoon) season is primarily due to intense precipitation which causes erosion of hill slopes and also because of melting of permafrost which can contribute to the available sediment.

The relationship between discharge and SSC (Figure 5) shows that SSC increases gradually with respect to discharge in the pre-monsoon season, whereas it increases rapidly from mid-June reaching a maximum concentration of $3211 \mathrm{mg} \cdot \mathrm{L}^{-1}$ on 2 July 2014 in the monsoon season. The maximum SSC almost doubles from morning (2242.6 $\left.\mathrm{mg} \cdot \mathrm{L}^{-1}\right)$ to the evening $\left(4179.4 \mathrm{mg} \cdot \mathrm{L}^{-1}\right)$ showing extreme diurnal variation in the monsoon season. This shows that precipitation plays an important role in shaping the sediment flow. To explore further the relationship between discharge and SSC, the coefficients of determination $\left(\mathrm{R}^{2}\right)$ were obtained for all the seasons.

The Kruskal Wallis test reveals that the test is statistically significant and there is significant variation among the four different seasons $(\mathrm{p}<0.05)$. The $\mathrm{R}^{2}$ values obtained were $0.41,0.33,0.69$ and 0.12 for pre-monsoon, monsoon, post-monsoon and winter seasons, respectively (Figure 6). The correlation was highest in the post-

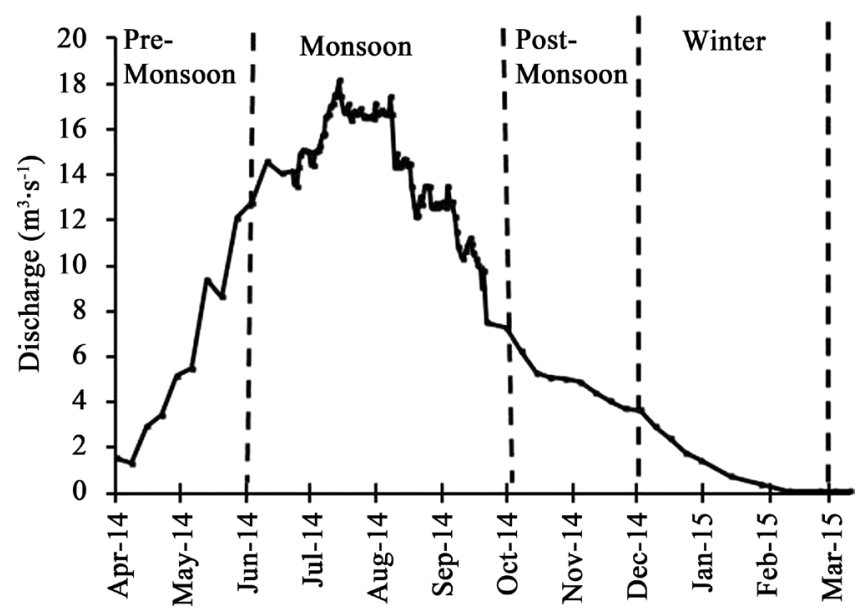

Figure 3. Distribution of discharge in Langtang River from April 2014 to March 2015.

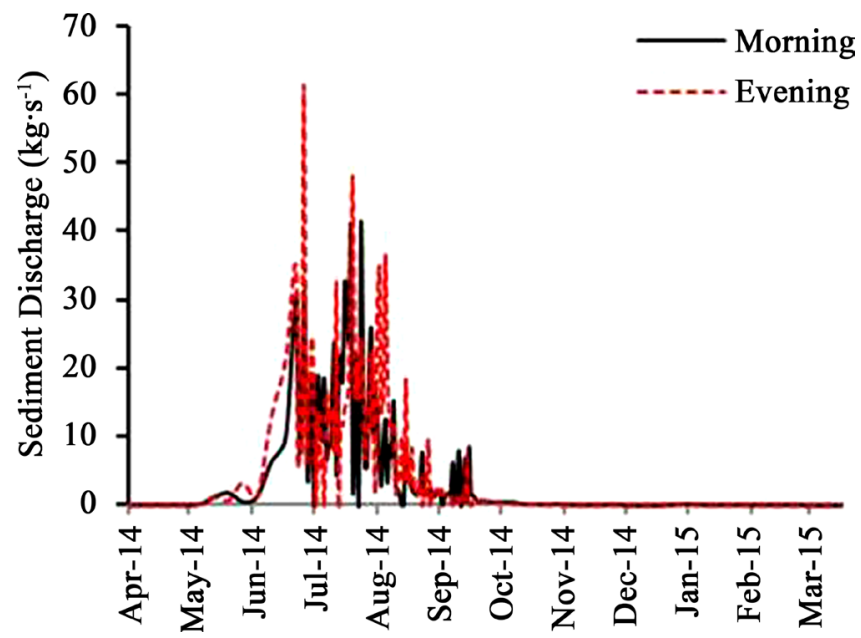

Figure 4. Diurnal variation of sediment discharge in Langtang River. 


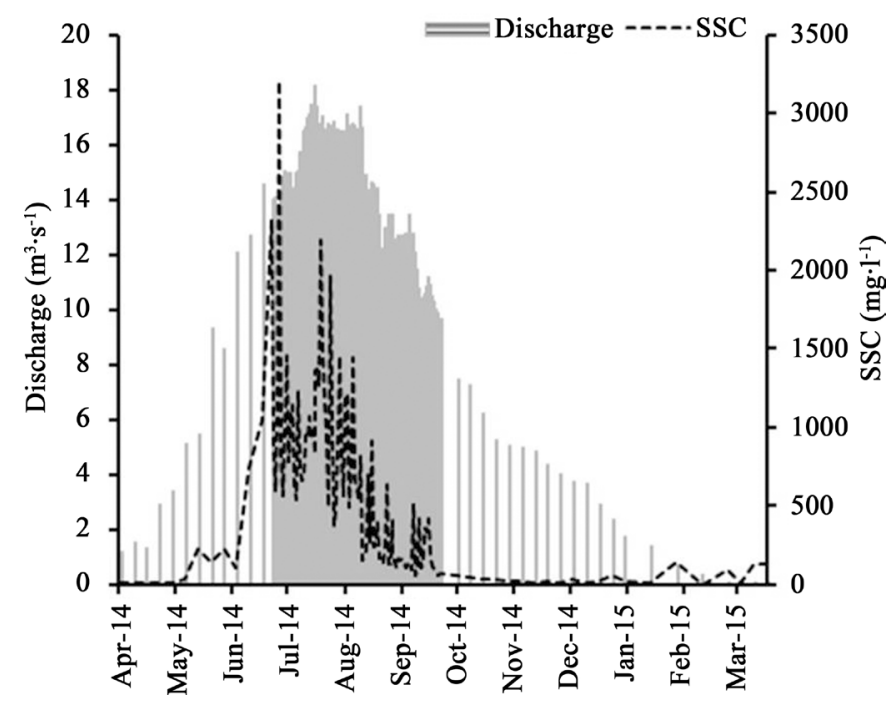

Figure 5. Distribution of discharge and SSC in Langtang River.
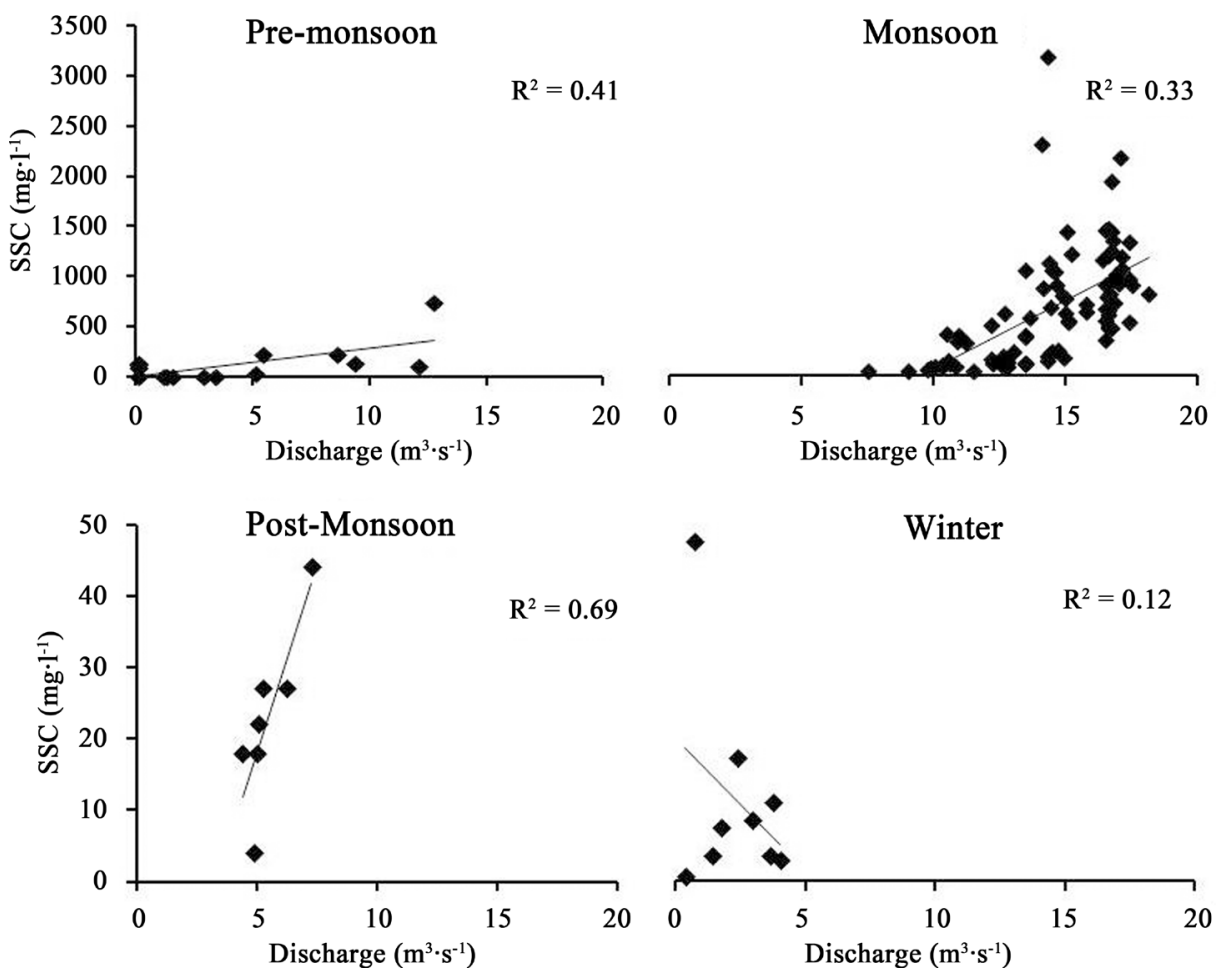

Figure 6. Correlation between discharge and SSC in pre-monsoon, monsoon, post-monsoon and winter seasons.

monsoon season. The $\mathrm{R}^{2}$ values were also obtained to study the relationship between discharge and sediment discharge and the results obtained were $\mathrm{R}^{2}=0.5, \mathrm{R}^{2}=0.42, \mathrm{R}^{2}=0.85$ and $\mathrm{R}^{2}=0.06$ for pre-monsoon, monsoon, post-monsoon and winter seasons, respectively as shown in Figure 7. This shows that that there is a positive and stronger relationship between sediment discharge and discharge in the post-monsoon season. This means that sediment contribution is not only affected by discharge but by other physical factors, likely including the weathering of rocks.

A clock-wise hysteresis loop has been obtained (Figure 8) for discharge and sediment discharge throughout the study period, where sediment flux is higher in the early monsoon than in the late monsoon for a corresponding discharge. This loop is formed due to the fact that most of the sediment has been mobilised during the early 

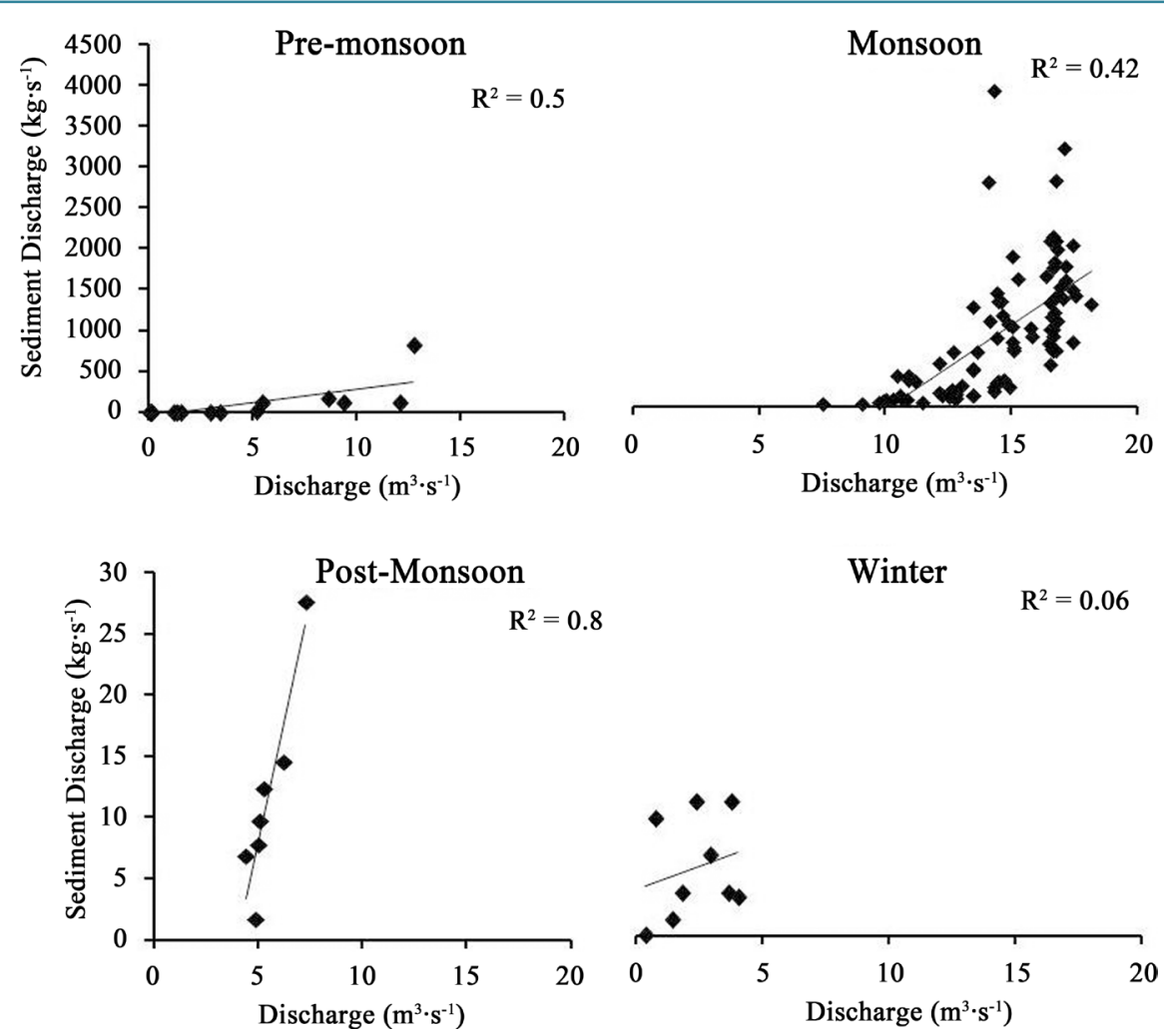

Winter

$\mathbf{R}^{2}=0.06$

Figure 7. Correlation between discharge and sediment discharge in pre-monsoon, monsoon, postmonsoon and winter seasons.

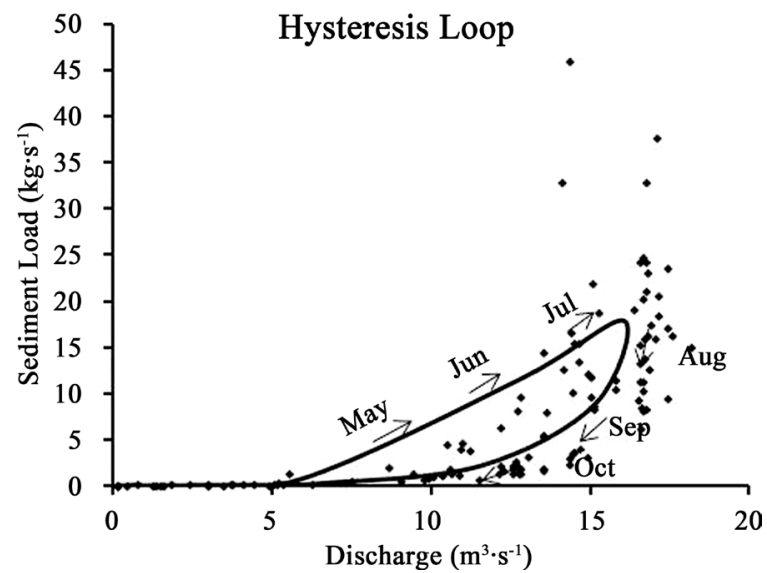

Figure 8. Clockwise hysteresis loop between SSC and discharge throughout the study period.

monsoon season, limiting its supply later in the season [19].

In the present study about $42.5 \%$ of annual sediment volume was transported in July. A similar study in Dokriani Glacier in the Central Himalayas, India found 52\% of annual sediment volume was transported in July [25]. An increase in melt water could cause dilution during these seasons and therefore decrease the amount of sediment concentration. But in this case, higher sediment concentration during the monsoon could also be due to an increase in stream cross sectional area and high availability of glacier debris [26]. An increase in the SSC from morning to evening was found in the Langtang River [15]. At Gangotri Glacier in the central Himalayas a direct correlation exists between SSC and discharge [26]. The poor correlation between discharge and SSC in a specific part of the monsoon is mainly due to the sudden increase in sediment concentration without a corresponding increase in discharge [12]. 


\section{Conclusions}

Sediment load of the Langtang River for all four seasons (pre-monsoon, monsoon, post-monsoon and winter) shows both diurnal and season effect on sediment content and discharge. The pre-monsoon and post-monsoon seasons account for transport of 37.69 and 11.52 tons of sediment per day, while the amount in the monsoon is 872.86 tons day $^{-1}$ with the lowest value of 5.54 tons day $^{-1}$ in the winter season. The annual sediment yield was $109,276.75$ tons in $2014-2015$. About $83 \%$ of the sediment was transported during the monsoon season. Sediment discharge reached a morning maximum of $41.1 \mathrm{~kg} \cdot \mathrm{s}^{-1}$ and a maximum of $61.5 \mathrm{~kg} \cdot \mathrm{s}^{-1}$ in the evening, clearly indicating that the daytime clean ice glacier melt is not a dilution effect. Instead, the influence of debriscovered melt and sub-surface flow paths is dominant.

Also, correlation between discharge and sediment discharge is found to be the strongest in the post-monsoon $\left(R^{2}=0.85\right)$ and the lowest in the winter season $\left(R^{2}=0.06\right)$. A clock-wise hysteresis loop has been obtained for discharge and sediment discharge and shows highest sediment flux in the early monsoon relative to the late monsoon for a corresponding discharge. A detailed and long-term study should be carried out to improve the understanding of sediment load in this river basin and inform water projects downstream.

\section{Acknowledgements}

We would heartily like to thank the Partnership for Enhanced Engagement in Research (PEER) Science Project funded by Unites States Agency for International Development (USAID) for granting us this opportunity to conduct this research. We are grateful to US Project Partner Mark W. Williams and Alana Wilson for their help to improve the manuscript. We are also grateful to the Department of Hydrology and Meteorology (DHM), Government of Nepal, Himalayan Cryosphere, Climate and Disaster Research Center (HiCCDRC), Kathmandu University and Cryosphere Monitoring Project-International Centre for Integrated Mountain Development, for their support and providing necessary data. Special thanks also goes to Mr. Jagat Kumar Bhusal of Society of Hydrology and Meteorology (SOHAM)—Nepal and Mr. Kuinga Tamang, station observer of DHM for their continuous co-operation.

\section{References}

[1] Collins, D.N. and Hasnain, S.I. (1994) Runoff and Sediment Transport from the Glacier Basins at the Himalayan Scale. International Association of Hydrological Sciences, 226, 17-25.

[2] Ives, J.D. and Messerli, B. (1989) The Himalayan Dilemma: Reconciling Development and Conservation. Psychology Press. http://dx.doi.org/10.4324/9780203169193

[3] Jain, S.K., Singh, P., Saraf, A.K. and Seth, S.M. (2003) Estimation of Sediment Yield for a Rain, Snow and Glacier Fed River in the Western Himalayan Region. Water Resources Management, 17, 377-393. http://dx.doi.org/10.1023/A:1025804419958

[4] Harbor, J. and Warburton, J. (1992) Glaciation and Denudation Rates. Nature, 356, 751. http://dx.doi.org/10.1038/356751a0

[5] Drewry, D. (1986) Glacial Geologic Processes. Vol. 276.

[6] Warburton, J. (1990) An Alpine Proglacial Fluvial Sediment Budget. Geografiska Annaler, 72A, 261-272. http://dx.doi.org/10.2307/521154

[7] Czuba, J.A., Magirl, C.S., Czuba, C.R., Grossman, E.E., Curran, C.A., Gendaszek, A.S. and Dinicola, R.S. (2011) Sediment Load from Major Rivers into Puget Sound and Its Adjacent Waters. U.S. Geological Survey Fact Sheet 3083, 4 p.

[8] Fujita, K., Thompson, L.G., Ageta, Y., Yasunari, T., Kajikawa, Y., Sakai, A. and Takeuchi, N. (2006) Thirty Year History of Glacier Melting in the Nepal Himalaya. Journal of Geophysical Research, 111. http://dx.doi.org/10.1029/2005jd005894

[9] Harris, C., Davies, M.C.R. and Etzelmüller, B. (2001) The Assessment of Potential Geotechnical Hazards Associated with Mountain Permafrost in a Warming Global Climate. Permafrost and Periglacial Processes, 12, 145-156. http://dx.doi.org/10.1002/ppp.376

[10] Galay, V.J., Schreier, H. and Bestbier, R. (2000) Himalayan Sediments Issue and Guidelines. Water and Energy Commission Secretariat, Nepal.

[11] Hasnain, S.I. (1996) Factors Controlling Suspended Sediment Transport in Himalayan Glacier Meltwaters. Journal of Hydrology, 181, 49-62. http://dx.doi.org/10.1016/0022-1694(95)02917-6 
[12] Arora, M., Kumar, R., Kumar, N. and Malhotra, J. (2014) Assessment of Suspended Sediment Concentration and Load from a Large Himalayan Glacier. Hydrology Research, 45, 292-306. http://dx.doi.org/10.2166/nh.2013.129

[13] Dhakal, B.N. (2009) Analysis of Channel Geometry and Sediment Transport in Palung and Chitlang Watersheds Using GIS. Journal of Hydrology and Meterology, 6, 66-75.

[14] Wang, F., Mu, X., Hessel, R., Zhang, W., Ritsema, C. and Li, R. (2013) Runoff and Sediment Load of the Yan River, China: Changes over the Last 60 yr. Hydrology and Earth System Sciences Discussion, 10, 1213-1249. http://dx.doi.org/10.5194/hessd-10-1213-2013

[15] Ohta, T., Fukushima, Y., Suzuki, M., Motoyama, H., Kawashima, K. and Kubota, H. (1987) Suspended Sediment Yield in a Glaciated Watershed of Langtang Valley, Nepal Himalayas. Bulletin of Glacier Research, 5, 19-24.

[16] Sangroula, D.P. (2009) Hydropower Development and Its Sustainability with Respect to Sedimentation in Nepal. Journal of the Institute of Engineering, 7, 1-9. http://dx.doi.org/10.3126/jie.v7i1.2063

[17] Thapa, B., Shrestha, R., Dhakal, P. and Thapa, B.S. (2005) Problems of Nepalese Hydropower Projects Due to Suspended Sediments. Aquatic Ecosystem Health and Management, 8, 251-257. http://dx.doi.org/10.1080/14634980500218241

[18] Immerzeel, W.W., VanBeek, L.P.H., Konz, M., Shrestha, A.B. and Bierkens, M.F.P. (2012) Hydrological Response to Climate Change in Glacierized Catchment in the Himalayas. Climate Change, 110, 721-736. http://dx.doi.org/10.1007/s10584-011-0143-4

[19] Andermann, C., Bonnet, S., Crave, A., Davy, P., Longuevergne, L. and Gloaguen, R. (2012) Sediment Transfer and the Hydrological Cycle of Himalayan Rivers in Nepal. Comptes Rendus Geoscience, 334, 627-635. http://dx.doi.org/10.1016/j.crte.2012.10.009

[20] Pradhananga, N.S., Kayastha, R.B., Bhattarai, B.C., Adhikari, T.R., Pradhan, S.C., Devkota, L.P., Shrestha, A.B. and Mool, P.K. (2014) Estimation of Discharge from Langtang River Basin, Rasuwa, Nepal, Using a Glacio-Hydrological Model. Annals of Glaciology, 55, 223-230. http://dx.doi.org/10.3189/2014AoG66A123

[21] USGS (2006) Collection of Water Samples, Version 2: U.S. Geological Survey Techniques of Water-Resources Investigations.

[22] APHA, AWWA and WEF (1999) Standards Methods for the Examination of Water and Wastewater. American Public Health Association, American Water Works Association and Water Environment Federation, Washington DC.

[23] Kayastha, R.B. and Shrestha, A. (2016) Snow and Ice Melt Contribution in the Daily Discharge of Langtang and Modi River, Nepal. Environment and Conservation in the Human-Dominated Himalaya, in Press.

[24] Wilson, A.M., Williams, M.W., Kayastha, R.B. and Racoviteanu, A. (2015) Use of a Hydrologic Mixing Model to Examine the Roles of Meltwater, Monsoon Precipitation, and Groundwater in the Langtang River Basin, Nepal. Annals of Glaciology, in Press.

[25] Hasnain, S.I. and Thayyen, R.J. (1999) Discharge and Suspended-Sediment Concentration of Meltwaters Draining from the Dokriani Glacier, Garhwal Himalaya, India. Journal of Hydrology, 218, 191-198. http://dx.doi.org/10.1016/S0022-1694(99)00033-5

[26] Singh, V.B., Ramanathan, A.L., Pottakkal, J.G. and Kumar, M. (2014) Seasonal Variation of Solute and Suspended Sediment Load in Gangotri Glacier Meltwater, Central Himalaya, India. Journal of Asian Earth Sciences, 79, $224-234$. http://dx.doi.org/10.1016/j.jseaes.2013.09.010 